\title{
Surgery in Refractory Amiodarone-Induced Thyrotoxicosis
}

\author{
Carine Ghassan Richa ${ }^{1,2 *}$, Mohamad Souheil El Rawas ${ }^{1,3}$ \\ ${ }^{1}$ Department of Endocrinology, Rafic El Hariri University Hospital, Beirut, Lebanon. \\ ${ }^{2}$ Endocrinology fellow, Lebanese University, Hadath, Lebanon. \\ ${ }^{3}$ Endocrinologist, Rafic El Hariri University Hospital, Beirut, Lebanon.
}

\begin{abstract}
Received: June 18, 2018; Accepted: July 02,2018; Published: July 11,2018
*Corresponding author: Carine Ghassan Richa, Department of Endocrinology, Rafic El Hariri University Hospital, Beirut, Lebanon, Tel: +961 70144157;Email: karinericha69@gmail.com
\end{abstract}

\section{Abstract}

Background: Thyroidectomy is a challenging treatment for refractory amiodarone induced thyrotoxicosis (AIT).

Objectives: The authors' aim in this article is to conduct a systematic review of the currently available literature regarding thyroidectomy for the treatment of refractory AIT.

Methods: The authors' systematic review yielded 14 studies encompassing 39 patients.

Results: All patients in this study developed thyrotoxicosis on amiodarone especially those with cardiac fragility and benefit from thyroidectomy to control all the symptoms of the hyperthyroid state without surgical risk or consequence on the cardiac status.

Conclusion: Thyroidectomy remains the definitive management of refractory AIT and should be instituted sooner rather than later in a patient suffering from this condition.

\section{Introduction}

Amiodarone is a class III anti-arrhythmic drug used to manage different cardiac problems, but its high iodine content and its direct toxic effect may cause thyroid dysfunction. Thyrotoxicosis is a harmful side effect of amiodarone use. Management of AIT is usually resistant to conventional methods and require prompt resolution of thyrotoxicosis-related cardiac decomposition. Definitive treatment can include surgery of the thyroid gland.

So here comes many studies about the safety and utility of thyroidectomy as definitive way to treat AIT and restore thyroid function.

The purpose of the present study was to systematically review the existing recent data regarding total thyroidectomy for the treatment of refractory AIT.

\section{Methods}

A review of the existing published data on thyroidectomy for the treatment of amiodarone induced thyrotoxicosis performed using PubMed for articles published in English. The terms used included amiodarone, thyrotoxicosis, thyroidectomy, amiodarone induced thyrotoxicosis. The search was not limited to any date range. 38 articles were identified and a total of 14 remained after duplicates were removed. 11 cases, 3 studies of case series reporting total thyroidectomy as definitive treatment for amiodarone induced thyrotoxicosis especially in those refractory to medical management.

\section{Results}

A total of 14 studies were included in this review article. All were published between 2002 and 2016 from different countries.

We have in total 39 patients, 23 were males, 16 were females and the age range varies between 32 and 82 .

All patients have heart problems and started amiodarone for atrial fibrillation, ventricular tachyarrythmias or dilated ischemic cardiomyopathy with heart failure and all these cardiac conditions were refractory to the usual medical or interventional therapy (drugs, implantable cardiac devices or even radiofrequency ablation).

The usual dose of amiodarone present is $200 \mathrm{mg}$ daily and the duration of amiodarone use extends from 6 months to 4 years and most of patients were admitted for thyrotoxicosis state ranging from recurrent rapid atrial fibrillation, decompensated heart failure to even thyroid storm which is reported in one case.

Laboratory tests in the 11 cases showed an elevated free or total thyroxine and triiodothyronine and suppressed TSH levels. In the 3 case-series, thyroid function tests were not identified. The reasons for intervention were failure of therapy to control thyrotoxicosis, persistence and deterioration of clinical symptoms and appearance of drug's side effects secondary to high doses used.(Table 1)

The definitive mechanism by which amiodarone has contributed to thyrotoxicosis, whether type 1 , type 2 or both, has been identified in most of the patients; in the 11 cases, 7 had type II AIT confirmed by either Doppler ultrasound which showed hypovascularization or by pathological features, 1 patient had type I AIT revealed by thyroid gland hypervascularization in addition to nodular goiter seen macroscopically and in 3 patients the exact mechanism was unknown. In the case -series of, all patients had destructive thyroiditis seen on pathology, in Lorberboym et al, type II AIT was established in the 11 patients and the type of AIT has not been mentioned [10,12,14]. 2 patients out of 39 had toxic MNG with pathology confirming type II AIT (they may have mixed disorder) and 1 patient had nodular goiter with unknown pathology. .(Table 2) 


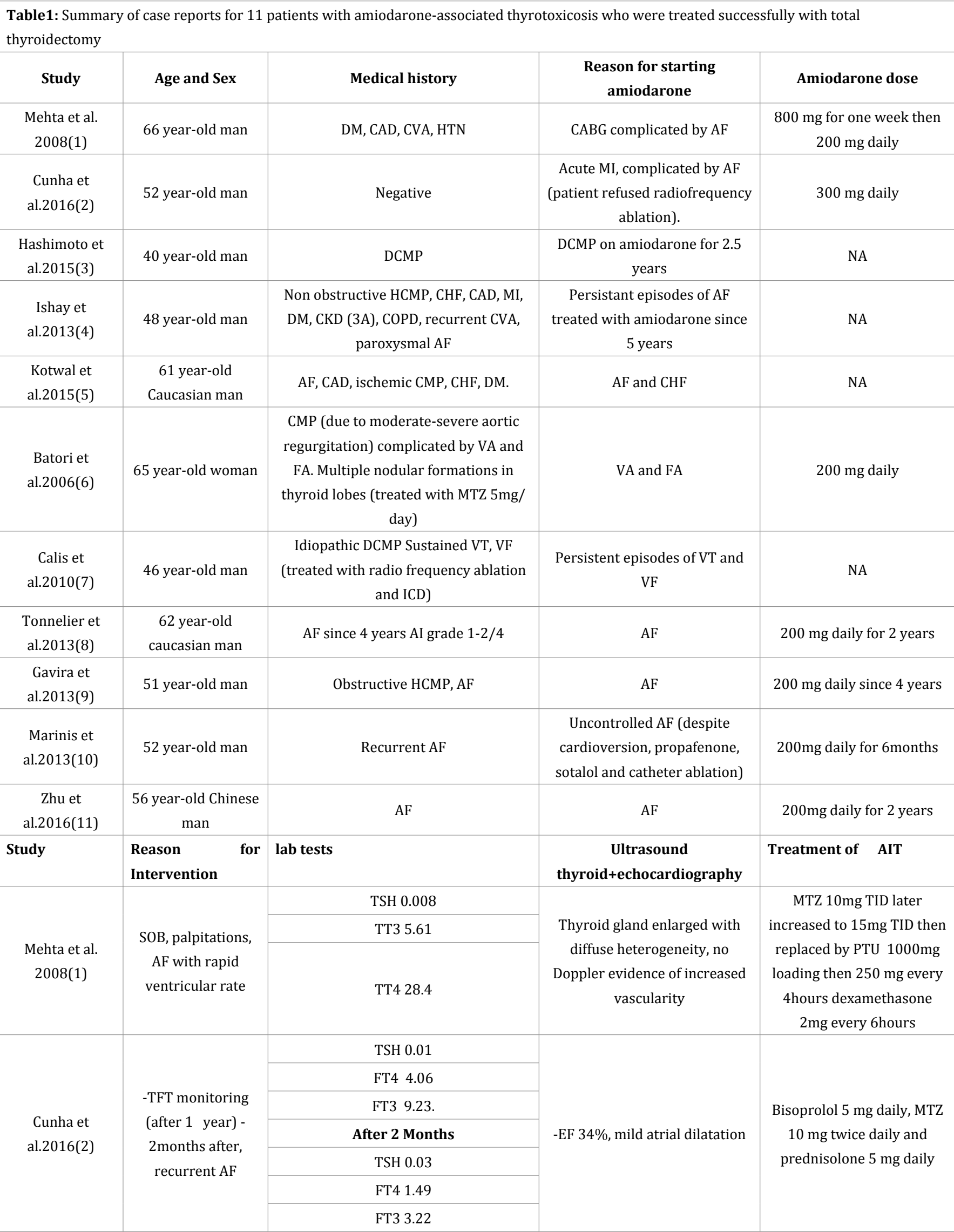




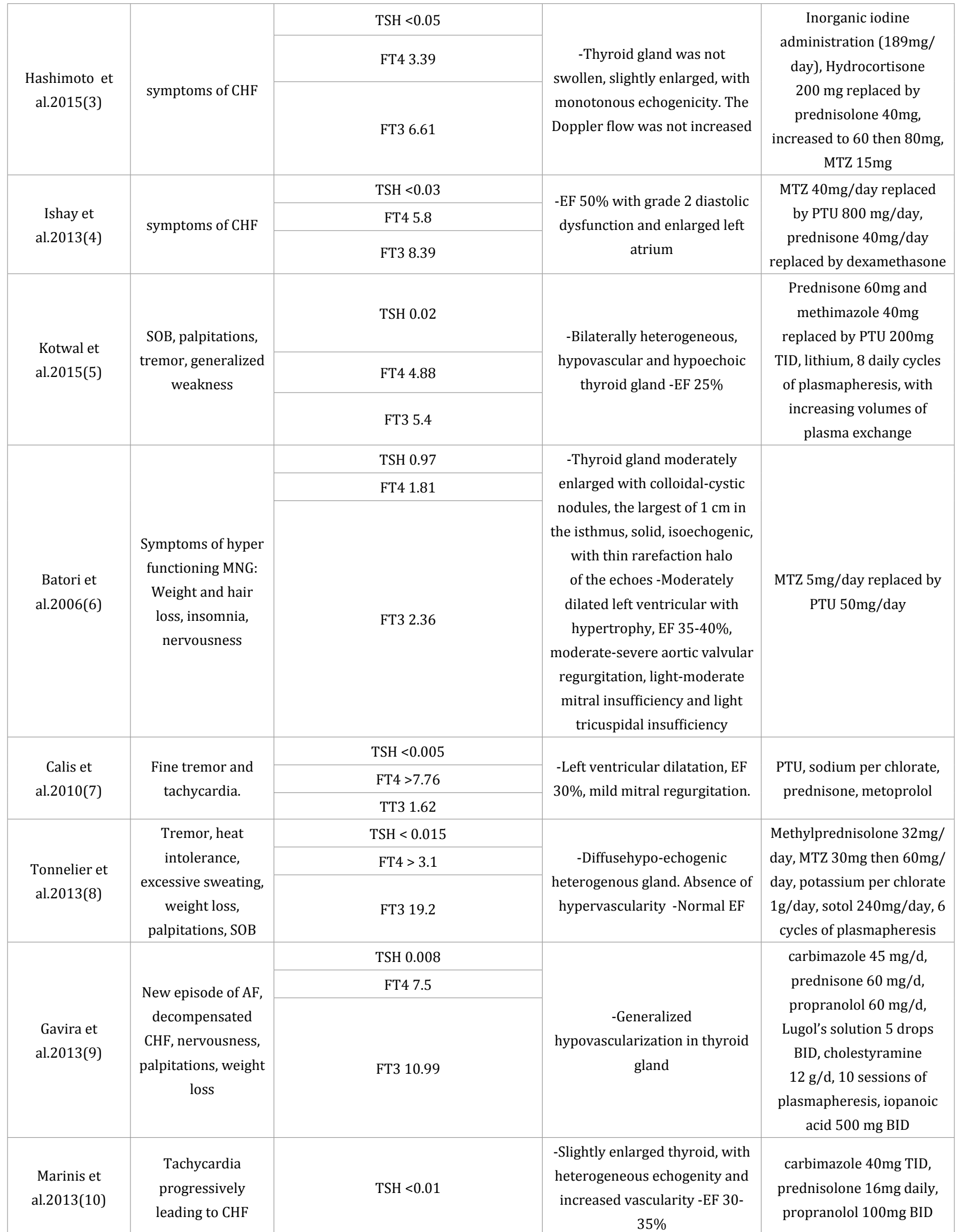




\begin{tabular}{|c|c|c|c|}
\hline \multirow[b]{3}{*}{$\begin{array}{c}\text { Zhu et } \\
\text { al.2016(11) }\end{array}$} & & TSH $<0.015$ & \multirow[b]{3}{*}{-Normal EF } \\
\hline & & FT4 4.97 & \\
\hline & $\begin{array}{l}\text { Fever }\left(40^{\circ} \mathrm{C}\right) \text {, } \\
\text { SOB, rapid } \mathrm{AF} \text {, } \\
\text { hypotension } \\
\text { (thyroid storm) }\end{array}$ & FT3 11 & \\
\hline Study & $\begin{array}{c}\text { PRE- } \\
\text { Thyroidectomy }\end{array}$ & POST-Thyroidectomy & Pathology \\
\hline $\begin{array}{l}\text { Mehta et al. } \\
\text { 2008(1) }\end{array}$ & $\begin{array}{l}\text { Despite maximal } \\
\text { medical therapy, } \\
\text { FT4 and TT3 } \\
\text { continued to } \\
\text { increase and TSH } \\
\text { remained below } \\
0.03\end{array}$ & $\begin{array}{l}\text { Clinically and biochemically euthyroid } \\
10 \text { days after thyroidectomy }\end{array}$ & $\begin{array}{l}\text { The gland was soft, not hypervascular. The epithelium in } \\
\text { many of the follicles was degenerated or partially denuded, } \\
\text { with vacuolated cytoplasm and pyknotic nuclei. Aggregates of } \\
\text { foamy histiocytes were found within the injured follicles, as } \\
\text { well as in the adjacent interstitium. These changes are typical } \\
\text { for amiodarone-induced thyroid injury }\end{array}$ \\
\hline $\begin{array}{l}\text { Cunha et } \\
\text { al.2016(2) }\end{array}$ & $\begin{array}{c}\text { Electrical cardio } \\
\text { version performed } \\
\text { then radiofrequency } \\
\text { ablation was } \\
\text { proposed for the } \\
\text { recurrent AF but } \\
\text { the patient refused. }\end{array}$ & $\begin{array}{l}\text { TFT improved gradually in } \\
\text { the first week and the patient } \\
\text { became asymptomatic. Control } \\
\text { echocardiography was normal, with EF } \\
\text { of } 59 \% \text {. }\end{array}$ & NA \\
\hline $\begin{array}{l}\text { Hashimoto et } \\
\text { al.2015(3) }\end{array}$ & $\begin{array}{l}\text { Overt thyrotoxicosis } \\
\text { was not controlled } \\
\text { despite } 2.5 \text { months } \\
\text { of steroids and } \\
\text { anti-thyroid drugs }\end{array}$ & $\begin{array}{l}\text { After surgery, the patient's } \\
\text { thyrotoxicosis rapidly disappeared, EF } \\
\text { ameliorated and TFT normalized with } \\
\quad 100 \mu \mathrm{g} \text { of levothyroxine }\end{array}$ & $\begin{array}{l}\text { Findings characterized by scattered follicle disruption, } \\
\text { vacuoles in epithelial cells, and macrophage infiltration, } \\
\text { compatible with amiodarone toxicity }\end{array}$ \\
\hline $\begin{array}{c}\text { Ishay et } \\
\text { al.2013(4) }\end{array}$ & $\begin{array}{c}\text { Persistant } \\
\text { symptoms of } \\
\text { decompensated } \\
\text { CHF (recurrent } \\
\text { pulmonary edema } \\
\text { with episodes of } \\
\text { supraventricular } \\
\text { and ventricular } \\
\text { tachycardia) }\end{array}$ & $\begin{array}{l}\text { Within } 2 \text { weeks of thyroidectomy, } \\
\text { patient developed hypothyroidism and } \\
\text { started on levothyroxine }\end{array}$ & $\begin{array}{l}\text { Macroscopically: small and fibrotic diffuse goiter } \\
\text { Microscopically: thyroid follicular cells were degenerated with } \\
\text { picnotic nuclei. Infiltration with foamy histiocytes was noted }\end{array}$ \\
\hline $\begin{array}{l}\text { Kotwal et } \\
\text { al.2015(5) }\end{array}$ & $\begin{array}{l}\text { Reccurent } \\
\text { symptoms with } \\
\text { poor response to } \\
\text { medical therapy } \\
\text { and increased } \\
\text { cardiovascular risk }\end{array}$ & $\begin{array}{l}\text { Within } 24 \text { hours, his FT4 and FT3 levels } \\
\text { decreased. On follow-up } 2 \text { months later, } \\
\text { he remained clinically euthyroid on } \\
\text { levothyroxine and maintained a stable } \\
\text { cardiac status. }\end{array}$ & $\begin{array}{l}\text { Macroscopically: a hard thyroid on both sides with } \\
\text { severe fibrosis and adhesions especially over the trachea. } \\
\text { Microscopically: intra-follicular histiocytes, patchy fibrosis } \\
\text { and involuted follicles, suggestive of destructive thyroiditis }\end{array}$ \\
\hline $\begin{array}{c}\text { Batori et } \\
\text { al.2006(6) }\end{array}$ & $\begin{array}{l}\text { No amelioration } \\
\text { depite anti-thyroid } \\
\text { drugs, reccurent } \\
\text { symptoms of CHF }\end{array}$ & Amelioration of thyrotoxic state & NA \\
\hline
\end{tabular}




\begin{tabular}{|c|c|c|c|}
\hline $\begin{array}{c}\text { Calis et } \\
\text { al.2010(7) }\end{array}$ & $\begin{array}{l}\text { No improvement in } \\
\text { TFT (TT3 and FT4 } \\
\text { remained high) }\end{array}$ & $\begin{array}{c}\text { Within several weeks, TFT improved } \\
\text { and the patient was started on } \\
\text { levothyroxine. }\end{array}$ & NA \\
\hline $\begin{array}{l}\text { Tonnelier et } \\
\text { al.2013(8) }\end{array}$ & $\begin{array}{l}\text { Worsening of } \\
\text { symptoms }\end{array}$ & $\begin{array}{l}\text { Rapid improvement of symptomatology } \\
\text { after thyroidectomy. Levothyroxine } \\
\text { was prescribed at day } 28 \text { post-surgery }\end{array}$ & NA \\
\hline $\begin{array}{l}\text { Gavira et } \\
\text { al.2013(9) }\end{array}$ & $\begin{array}{c}\text { Worsening of } \\
\text { hyperthyroidism } \\
\text { (TSH 0.008, } \\
\text { FT4 >7.7 and } \\
\text { FT3 15.14), } \\
\text { uncontrolled atrial } \\
\text { flutter }\end{array}$ & $\begin{array}{l}\text { After } 12 \text { months of follow-up on } \\
\text { treatment with levothyroxine } 125 \mathrm{mcg} / \\
\text { day, the patient has experienced no } \\
\text { new episodes of tachyarrhythmia. }\end{array}$ & $\begin{array}{l}\text { Normal sized thyroid gland with no nodules, involution of } \\
\text { thyroid follicles, and degenerative changes. }\end{array}$ \\
\hline $\begin{array}{l}\text { Marinis et } \\
\text { al.2013(10) }\end{array}$ & $\begin{array}{l}\text { Persistant } \\
\text { tachycardia and } \\
\text { abnormal TFT }\end{array}$ & $\begin{array}{l}2 \text { weeks after thyroidectomy, the } \\
\text { patient experienced better tolerance of } \\
\text { physical activity, reduced his } \beta \text {-blocker } \\
\text { regimen and demonstrated a higher EF } \\
(50 \%) \text {. One month postoperatively, the } \\
\text { patient has discontinued his } \beta \text {-blocker } \\
\text { and has returned to normal daily } \\
\text { activity. }\end{array}$ & Nodular goiter with follicular hyperplasia \\
\hline $\begin{array}{c}\text { Zhu et } \\
\text { al.2016(11) }\end{array}$ & $\begin{array}{c}\text { Refractory } \\
\text { tachycardia, } \\
\text { therapeutic options } \\
\text { were limited } \\
\text { by the severe } \\
\text { derangement of } \\
\text { liver function. }\end{array}$ & $\begin{array}{l}\text { After thyroidectomy, there was a } \\
\text { significant drop of FT4, FT3 and heart } \\
\text { rate. } 12 \text { months after discharge, his TFT } \\
\text { were stable on thyroxine replacement. }\end{array}$ & $\begin{array}{l}\text { Microscopically, there was a predominance of colloid } \\
\text { containing thyroid follicles. Several features compatible with } \\
\text { type II AIT were seen, including foamy histiocytes, vacuolated } \\
\text { desquamated epithelial cells and multinucleated giant cells }\end{array}$ \\
\hline \multicolumn{4}{|c|}{$\begin{array}{l}\text { DM: diabetes mellitus CAD: coronary artery disease CVA: cerebrovascular accident AF: atrial fibrillation } \\
\text { CABG: coronary artery bypass graft MI: myocardial infarction DCMP: dilated cardiomyopathy CHF: congestive heart failure CKD: chronic kidney } \\
\text { disease COPD: chronic obstructive pulmonary disease CMP: cardiomyopathy } \\
\text { VA: ventricular arrhythmia MTZ: methimazole VT: ventricular tachycardia VF: ventricular fibrillation AI: aortic insufficiency SOB: shortness of } \\
\text { breath TFT: thyroid function test MNG: multinodular goiter NA: not available } \\
\text { TSH (thyroid stimulating hormone) }: 0.35-5.5 \mathrm{mIU} / \mathrm{l} \\
\text { TT4 (total thyroxine) : } 4.5-12 \mathrm{mcg} / \mathrm{dl} \\
\text { TT3 (total triiodothyronine) }: 0.6-1.81 \mathrm{ng} / \mathrm{ml} \\
\text { FT4 (free thyroxine) : } 0.61-1.12 \mathrm{ng} / \mathrm{dl} \\
\text { FT3 (free triiodothyronine) }: 2.5-3.9 \mathrm{pg} / \mathrm{ml}\end{array}$} \\
\hline
\end{tabular}




\begin{tabular}{|c|c|c|c|c|c|c|c|c|c|}
\hline study & $\begin{array}{l}\text { Age } \\
+\operatorname{sex}\end{array}$ & $\begin{array}{l}\text { Past medical } \\
\text { history }\end{array}$ & $\begin{array}{l}\text { Reason for } \\
\text { starting } \\
\text { amiodarone }\end{array}$ & Reason for intervention & $\begin{array}{c}\text { Duration of } \\
\text { amiodarone } \\
\text { use }\end{array}$ & $\begin{array}{c}\text { Treatment of } \\
\text { AIT }\end{array}$ & $\begin{array}{c}\text { Pre- } \\
\text { Thyroidectomy }\end{array}$ & $\begin{array}{c}\text { Post- } \\
\text { Thyroidectomy }\end{array}$ & Pathology \\
\hline $\begin{array}{c}\text { Gouch et } \\
\text { al.2002(12) }\end{array}$ & $\begin{array}{l}82 \text { year- } \\
\text { old } \\
\text { female }\end{array}$ & $\begin{array}{c}\text { Toxic MNG } \\
\text { treated with } \\
\text { carbimazole for } \\
20 \text { years }\end{array}$ & $\mathrm{AF}$ & thyrotoxicosis & 4 months & $\begin{array}{l}\text { PTU, prednisone, } \\
\text { potassium per } \\
\text { chlorate. }\end{array}$ & $\begin{array}{l}\text { Failure of } \\
\text { therapy } \\
\text { to control } \\
\text { thyrotoxicosis }\end{array}$ & $\begin{array}{c}\text { patients } \\
\text { recovered } \\
\text { rapidly and } \\
\text { remain well } \\
\text { and euthyroid } \\
\text { on thyroxine } \\
\text { replacement }\end{array}$ & $\begin{array}{c}\text { Destruction of } \\
\text { follicles, and } \\
\text { macrophages } \\
\text { in the colloid. } \\
\text { Marked } \\
\text { inflammatory } \\
\text { cell } \\
\text { infiltration. } \\
\text { Fibroblasts } \\
\text { creating } \\
\text { fibrous tissue. }\end{array}$ \\
\hline $\begin{array}{c}\text { Gouch et } \\
\text { al.2002(12) }\end{array}$ & $\begin{array}{l}39 \text { year- } \\
\text { old } \\
\text { man }\end{array}$ & $\begin{array}{l}4 \text { operations } \\
\text { for tetralogy } \\
\text { of Fallot and } \\
\text { on waiting list } \\
\text { for cardiac } \\
\text { transplantation }\end{array}$ & Recurrent VT & $\begin{array}{l}\text { worsening VT due to } \\
\text { thyrotoxicosis(requiring } \\
\text { automatic implanted } \\
\text { cardiac defibrillator) }\end{array}$ & 3 years & $\begin{array}{l}\text { carbimazole, } \\
\text { prednisone, } \\
\text { potassium } \\
\text { per chlorate } \\
\text { and lithium } \\
\text { carbonate }\end{array}$ & $\begin{array}{l}\text { Failure of } \\
\text { therapy } \\
\text { to control } \\
\text { thyrotoxicosis }\end{array}$ & Same as before & $\begin{array}{l}\text { Same as } \\
\text { before. }\end{array}$ \\
\hline $\begin{array}{c}\text { Gouch et } \\
\text { al.2002(12) }\end{array}$ & $\begin{array}{c}32 \text { year- } \\
\text { old } \\
\text { man }\end{array}$ & Familial DCMP & recurrentVT & $\begin{array}{l}\text { Thyrotoxicosis for } 18 \\
\text { months. CHF : EF } 4 \%\end{array}$ & 4 years & $\begin{array}{l}\text { PTU, potassium } \\
\text { per chlorate } \\
\text { and lithium } \\
\text { carbonate. }\end{array}$ & $\begin{array}{c}\text { Failure of } \\
\text { therapy } \\
\text { to control } \\
\text { thyrotoxicosis }\end{array}$ & Same as before & $\begin{array}{l}\text { Same as } \\
\text { before }\end{array}$ \\
\hline $\begin{array}{c}\text { Gouch et } \\
\text { al.2002(12) }\end{array}$ & $\begin{array}{l}61 \text { year- } \\
\text { old } \\
\text { man }\end{array}$ & $\begin{array}{c}\text { Rheumatic } \\
\text { heart } \\
\text { disease with } \\
\text { aortic valve } \\
\text { replacement } \\
\text { and congestive } \\
\text { cardiac failure }\end{array}$ & $\begin{array}{l}\text { Ventricular } \\
\text { tachycardia } \\
\text { and } \\
\text { fibrillation }\end{array}$ & $\begin{array}{l}\text { Thyrotoxicosisdeveloped } \\
\text { two months after } \\
\text { amiodarone was } \\
\text { discontinued. }\end{array}$ & two years & $\begin{array}{l}\text { propylthiouracil, } \\
\text { prednisone } \\
\text { and lithium } \\
\text { carbonate. }\end{array}$ & $\begin{array}{l}\text { Failure of } \\
\text { therapy } \\
\text { to control } \\
\text { thyrotoxicosis }\end{array}$ & Same as before & $\begin{array}{l}\text { Same as } \\
\text { before }\end{array}$ \\
\hline $\begin{array}{c}\text { Gouch et } \\
\text { al.2002(12) }\end{array}$ & $\begin{array}{c}63 \text { year- } \\
\text { old } \\
\text { man }\end{array}$ & $\begin{array}{l}\text { CABG and } \\
\text { cardiac } \\
\text { pacemaker. }\end{array}$ & FA & $\begin{array}{c}\text { Thyrotoxicosis } \\
\text { developed } 3 \text { months } \\
\text { after amiodarone was } \\
\text { discontinued }\end{array}$ & 2 years & $\begin{array}{l}\text { carbimazole and } \\
\text { prednisolone }\end{array}$ & $\begin{array}{l}\text { Failure of } \\
\text { therapy } \\
\text { to control } \\
\text { thyrotoxicosis }\end{array}$ & Same as before & $\begin{array}{c}\text { Same as } \\
\text { before }\end{array}$ \\
\hline
\end{tabular}

Many trials were conducted to control the hyperthyroid state, from anti-thyroidal drugs (high doses of thionamides $(60 \mathrm{mg} /$ day) and propylthiouracil (1200 mg)) to high doses of corticosteroids, iodine solution, cholestyramine and even plasmapheresis, without any benefit. In all cases, thyrotoxicosis was refractory to these different treatment modalities, unresponsive with worsening of the underlying cardiac conditions in several cases and the only solution remains total thyroidectomy whether they had type I (underlying thyroid pathology) or type II AIT (destructive thyroiditis). .(Table 3)

All patients ameliorated after thyroidectomy and restored the euthyroid state with improvement of symptoms and ventricular function. Only one died after surgery but this is secondary to his preexisting comorbid conditions. 


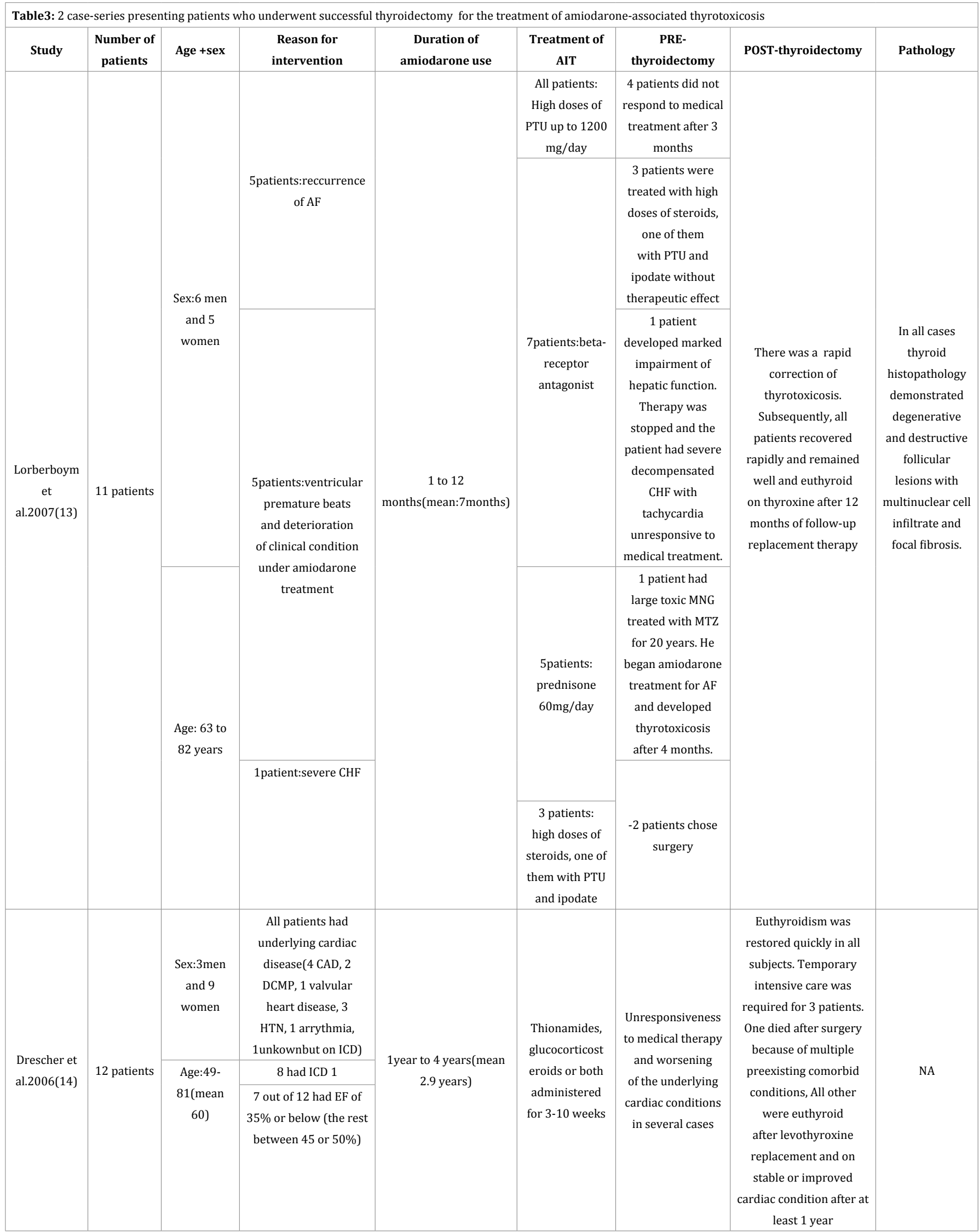




\section{Discussion}

Amiodarone is a widely used anti-arrhythmic drug treating mainly supraventricular and ventricular tachycardia's, used safely in patients with atrial fibrillation and heart failure in order to obtain sinus rhythm without affecting ventricular function.

However, like any other drug, its benefit can be out weighted by numerous side effects especially that most individuals administered it on a chronic basis so they will experience definitely at least one side effect among others. The most hazardous one is thyroid dysfunction (hypo or hyperthyroidism) as amiodarone is an iodine rich compound and similar structurally to thyroid hormone. (1)

Some patients on amiodarone remain euthyroid but others develop thyrotoxicosis and have consequently higher adverse cardiovascular events.

Amiodarone-induced thyrotoxicosis (AIT) is a serious complication of long-term amiodarone use. It occurs in patients with already established cardiac dysfunction on amiodarone, who didn't tolerate the hyperthyroid state. It is classified as iodine-induced thyrotoxicosis (type 1) existing in patients with underlying thyroid disease exacerbated by thyroid autonomous function, mainly in iodine-deficient areas and destructive thyroiditis (type 2) in those with no history of thyroid problems causing direct cytotoxic and inflammatory effects, occurring in iodine-repleted areas. [4] Mixed forms also are present. Those effects are probably due to high iodine content of amiodarone, and its long half-life (107 days). [2]

Changes seen microscopically in type I AIT are consisting of preexisting thyroid disease, usually multinodular goiter or underlying latent Graves disease, in whom iodine exposure triggers the development of clinical disease. This subgroup usually has normal or only slightly elevated serum levels of interleukin-6, while patients with type 2 AIT have randomly distributed disrupted follicules, filled with desquamated vacuolated epithelial cells, foamy macrophages and lymphocytes, involutional changes and fibrosis. They have higher levels of IL-6, rendering it a good marker of the thyroid-destructive processes. [13] Thyroid scan and doppler ultrasound can differentiate also between the 2 types. Absence of tracer uptake in the thyroid bed and Doppler flow demonstrate type 2 AIT.

The exact type of thyrotoxicosis cannot be identified most of the time and treatment for both conditions is given. [2] Mixed cases of amiodarone induced thyrotoxicosis occur in 15 to $27 \%$ of cases. [4]

In patients with preexisting cardiac disease, the effect on heart is more worrisome. When established, AIT worsens the underlying arrhythmia and most patients developed decompensated heart failure, recurrent atrial fibrillation or any arrhytmia because of the superimposed hyperthyroid state. [3]

Hyperthyroidism may be mild (free thyroxine (T4) levels 1 to 1.5 times the upper limit of normal), moderate (free T4 levels 1.5 to 2 times the upper limit of normal) or severe (free T4 levels approximately 2 to 3 times the upper limit of normal).
AIT is a challenging problem difficult to manage with substantial morbidity and mortality especially in elderly patients with signs and symptoms of cardiac instability. Thus, resolution of this severe hyperthyroid state is crucial.

Ideally, amiodarone should be discontinued but cessation of this potent drug is impractical in some patients because it is the only anti-arrhythmic capable of controlling tachyarrhythmias, and even if it can be stopped, AIT can take up to nine months to resolve, its effect may last seven years. When stopping amiodarone, a loss of beta blockage may exacerbate thyrotoxicosis which may not improve and lead to comorbid cardiac conditions and major problems. [2]

Many trials of medical therapy with anti-thyroid drugs, steroids, radioactive iodine, plasmapheresis failed due to the high intrathyroidal iodine content that reduces the efficacy of thionamides which also have many side effects and complications, the low suppressed RAI uptake mainly in type II and the refractoriness of AIT to steroids and plasmapheresis. [13]

Thionamides, usually with a short course of potassium per chlorate are beneficial, and if no response we can add steroids but the effect of medical therapy may take as long as 4 months to be efficient. [7]

Major anti-thyroid drugs are able to temporary control symptoms but all are hepatotoxic especially that treatment requires high doses, steroids can reduce the inflammation but have major side effects, plasmpharesis can provide acute relief of type 2 amiodarone induced thyrotoxicosis but its effect is transient, with higher cost and impossibility of long term use. Radioactive iodine is not feasible in all conditions especially in type 2 because of a low uptake. [3]

Clinical manifestations and morbidity of thyrotoxicosis leading even to thyroid storm, can be the reason for choosing thyroidectomy as the only curative solution. Many series have reported the successful surgical management of amiodaroneinduced thyrotoxicosis.[15]

Most studies have shown that total thyroidectomy reduce mortality and morbidity, despite that euthyroidism is difficult to achieve. None of those case series presented here showed a significant complication post thyroidectomy, despite the risk of anesthesia associated with thyrotoxicosis, mainly in patients with heart disease, and the high surgical risk. The anesthetic management should be considered. Patients with mild hyperthyroidism do not require special considerations while those with severe Intraoperative hyperthyroidism (thyrotoxic storm secondary to manipulation of the thyroid gland during thyroidectomy] may require hydration, cooling, and administration of antithyroid drugs, beta-blockers and sodium iodine to prevent any hyperthyroid crisis (storm].[29]. Thus, it is preferable to control hyperthyroid and to restore euthyroidism before thyroidectomy but in most cases, there is a necessity for an urgent treatment before establishing a normal euthyroid state.

When surgery is performed, the postoperative risk of arrhythmias, hemodynamic compromise, and thyroid storm is very minimal. 
All patients improved clinically, in addition to amelioration of their cardiac status. Those in whom discontinuing amiodarone is not feasible can be also referred to surgery. [6]

\section{Conclusion}

As amiodarone can cause thyroid dysfunction and thyrotoxicosis especially in patients with preexisting heart problems, checking for and treatment of amiodarone induced thyrotoxicosis is important. Total thyroidectomy is an effective method for treatment of amiodarone induced thyrotoxicosis unresponsive to medical therapy, because of severe cardiac morbidity and mortality associated with overt hyperthyroidism.

\section{Acknowledgement}

we sharing our gratitude towards the Novo Nordisk company for their financial support to our Research paper.

\section{References}

1. Mehta AN, Vallera RD, Tate CR, Sager RA, Welch BJ. Total thyroidectomy for medically refractory amiodarone-induced thyrotoxicosis. Proc Bayl Univ Med Cent. 2008;21(4):382-385.

2. Marques-Cunha M, Costa G, Gomes M, Moura F. Total thyroidectomy in a patient with amiodarone- induced thyrotoxicosis and thiamazole related hepatotoxicity. The Greek E-Journal of Perioperative Medicine. 2016;15(c):101-106.

3. Hashimoto K, Ota M, Irie T, Takata D, Nakajima T, Kaneko Y, et al. A Case of Type 2 Amiodarone-Induced Thyrotoxicosis That Underwent Total Thyroidectomy under High-Dose Steroid Administration. Case Rep Endocrinol.2015;2015: 416145. Doi: 10.1155/2015/416145

4. Ishay A, Carmeli J, Rozner E, Luboshitzky R. Refractory Amiodaroneinduced Thyrotoxicosis: The Surgical Option. Agarwal A, editor. World J Endocr Surg. 2013;5(1):21-24.

5. Kotwal A, Touchan B, Seetharaman KY, Haas RA, Lithgow M, Malkani S. Mixed Amiodarone-Induced Thyrotoxicosis Refractory to Medical Therapy and Plasmapheresis. J Endocrinol Metab. 2015;5(3):220223. Doi: $10.14740 /$ jem $278 w$
6. Batori M, Nardi M, Chatelou E, Straniero A, Makrypodi M, Ruggieri M. Total thyroidectomy in amiodarone-induced thyrotoxicosis. Preoperative, intraoperative and postoperative considerations. Eur Rev Med Pharmacol Sci. 2006;10(4):187-190.

7. Calis P, Berendsen R, Logeman A, Sarton E, Aarts L. Anesthetic Considerations in a Patient with Amiodarone-Induced Thyrotoxicosis. Case Rep Med. 2010;2010:984981. Doi: 10.1155/2010/984981

8. Tonnelier A, de Filette J, De Becker A, Deweer S, Velkeniers B. Successful Pretreatment Using Plasma Exchange before Thyroidectomy in a Patient with Amiodarone-Induced Thyrotoxicosis. Eur Thyroid J. 2017;6(2):108-112. Doi: 10.1159/000453578

9. Mateo Gavira I, Vilchez López F, Larrán Escandón L, Roldán Caballero P, Aguilar Diosdado M. Management of severe amiodarone-induced thyrotoxicosis after failure of standard medical treatment. Endocrinol Nutr Engl Ed. :e43-45.

10. Marinis A, Vassilopoulos G, Avraamidou A, Vassilakaki T, Bassioukas P, Rizos S. Successful surgical treatment of refractory amiodaroneinduced thyrotoxicosis causing tachycardiomyopathy. Hell J Surg. 2013;85(5):347-350.

11.Zhu L, Zainudin SB, Kaushik M, Khor LY, Chng CL. Plasma exchange in the treatment of thyroid storm secondary to type II amiodaroneinduced thyrotoxicosis. 2016; EDM160039. Doi: 10.1530/EDM-160039

12. Gough IR, Gough J. Surgical management of amiodarone-associated thyrotoxicosis. 2002;176:128-129.

13. Mordechai Lorberboym, Pinhas Schachter. Drug-Induced Thyrotoxicosis: The Surgical Option. 2007;9:79-82.

14. Drescher T, Clerici T, Kolb W, Brandle M, Bilz S. Total thyroidectomy in refractory amiodarone induced thyrotoxicosis: a case series of 12 patients. Endocr Abstr. 2016;41:EP1016. Doi: 10.1530/endoabs.41. EP1016

15.GursoyAlptekin, Neslihan BascilTutuncu, CuneydAnil, Asli NarDemirer, Nilgun GuvenerDemirag, ArzuGencoglu. Radioactive Iodine in the Treatment of Type-2 Amiodarone-Induced Thyrotoxicosis -ScienceDirect. 2008;100(6):716-720. Doi: 10.1016/ S0027-9684(15)31348-1 